\title{
Information Literacy Didactics for Higher Education and Research: Some Lessons from an International Workshop
}

\author{
Paul Nieuwenhuysen \\ Vrije Universiteit Brussel, Brussels, Belgium \\ Paul.Nieuwenhuysen@vub.ac.be
}

\begin{abstract}
This contribution identifies challenges in information literacy didactics in contemporary higher education all over the world:

- Heterogeneity among organizations for higher education hinders co-operation.

- Information literacy is competing with media literacy.

- Leadership and responsibility are needed in information literacy education.

- Developing information literacy training materials requires an adequate budget.

- Expertise in didactics is also needed for teaching in the area of information literacy.

- Marketing should support information literacy didactics.

- Information literacy should be integrated in the curriculum of all students.

- Libraries should not neglect contemporary information systems.

- Study materials should be adapted to the upcoming mobile information technology tools.

- Regional training and workshops on information literacy didactics would be welcome.

- Data management skills become important besides information literacy.
\end{abstract}

These challenges should be faced constructively and therefore we formulate for each challenge also a recommendation towards stakeholders.

This paper is based mainly on recent project activities of organizations of higher education in Flanders, Belgium, aimed at

1. getting a view on the growing expertise in didactics to upgrade the level of information literacy in their region, and paving the way towards more efficient cooperation on information literacy didactics with partner universities, mainly in developing countries,

2. sharing their experience with universities in developing countries, in Asia, Africa and

Material published as part of this publication, either on-line or in print, is copyrighted by the Informing Science Institute. Permission to make digital or paper copy of part or all of these works for personal or classroom use is granted without fee provided that the copies are not made or distributed for profit or commercial advantage AND that copies 1) bear this notice in full and 2) give the full citation on the first page. It is permissible to abstract these works so long as credit is given. To copy in all other cases or to republish or to post on a server or to redistribute to lists requires specific permission and payment of a fee. Contact Publisher@InformingScience.org to request redistribution permission.
America, in the form of a fruitful international workshop and follow-up activities.

Keywords: Information literacy, didactics, information centers, co-operation, Internet, higher education. 


\section{Introduction}

\section{Information Literacy}

Most people can only function and live well in our complex society, when they have acquired elements of information literacy. Which elements and level of information literacy is adequate depends of course on many factors. The awareness of this need is growing, due to the evolution of our society:

- Access to information has become easier due to more affordable information technology.

- More jobs rely on coping with information and less on physical work.

- Our information landscape is getting more complex and is evolving at an increasing speed.

So information literacy is perhaps more important than ever. This evolution is reflected for instance in the annual European Conference on Information Literacy, which has started in 2013 and which attracts a lot of interest (see http://ecil2013.ilconf.org/ Kurbanoglu, 2013; http://ecil2014.ilconf.org/, Kurbanoglu et al., 2014; http://ecil2015.ilconf.org/ ). As a consequence information literacy education also becomes more important in education in general and in higher education in particular. More references to publications in the area of information literacy have been included in the toolkit on the WWW that has been developed in the framework of the project described in this paper and that is described in the appendix. A recent book emphasizes the extension of the relatively classical concept "information literacy" to a broader concept that the authors cover with the word "metaliteracy" (Jacobson and Mackey, 2016).

This contribution deals mainly with how to optimize educational methods (didactics) to increase the level of information literacy of students and researchers in organizations for higher education and research.

\section{Belgium Promotes International University Co-Operation}

Belgium is a small country in Europe. The government supports international co-operation. In particular, funds are provided to universities and other institutes for higher education to support activities with similar partner institutes in developing countries. In the northern region of Belgium, named Flanders, the funds are allocated to the association of universities, which is named VLIR (and which stands for Vlaamse Interuniversitaire Raad). Therefore VLIR has established a unit to deal with these funds and to use these for projects that are managed by particular universities in the region (see http://www.vliruos.be/).

Most funds go to co-operation programs in which several universities in Flanders work with a particular university in a developing country. Recently also larger programs have been started: in each one, all interested universities in Flanders work with a network of universities in a priority partner country. Each of these programs consists of several projects that are subject- or problemoriented, the so-called vertical projects. In general a few other projects are dedicated to university-wide development, the so-called horizontal projects; an example is promoting and supporting applications of information technology, to implement more e-learning, to improve discovery of scientific and professional information sources and to improve access to relevant documents.

Funding goes also to international educational programs such as

- relatively long international Master Programs 
- relatively short International Training Programs; see for instance a description of such programs related to information management (Nieuwenhuysen, 2010).

Also some support goes to short projects that involve more than one university in developing countries, to enhance international co-operation among universities in developing countries and to spread the experience gained by one university in some previous project; the umbrella name for these projects is North-South-South co-operation.

Furthermore, horizontal short projects can support more than one university partner in developing countries on topics that are of interest to most partners, such as management of Internet bandwidth, e-learning, information discovery, and information literacy.

\section{Project on International Co-Operation in Information Literacy Didactics}

The international co-operation that is sketched above forms the context for the activities reported here. We submitted a proposal to the association of universities in Flanders, Belgium, to carry out a project of a few months in 2014, with the aim of sharing expertise with partners in developing countries on how to increase the level of information literacy in higher education. The hope was then of course that this would lead to capacity building in information literacy didactics and eventually also to higher levels of information literacy among students and researchers in the partner universities in the partner countries. More concrete project components were the following:

1. To create a useful overview of experts and expertise available in Belgium to support a workshop on information literacy with partners from developing countries and to pave the road for later application of this expertise in international cooperation projects.

2. To prepare and organize a two-week workshop on information literacy didactics, hosted by the University of Antwerp, with contributions from Belgium, from neighboring countries, and from partners in developing countries.

3. To identify useful, relevant, existing initiatives and tools related to information literacy didactics and to bring these together in an online toolkit on the World Wide Web, to support the workshop and later activities, mainly in international co-operation with the partners.

The Appendix give more details about

- the management of the project,

- the invitation and selection of participants to the workshop,

- the program of the workshop.

This project was closely related to another project with an analogous structure, but with other invited participants and of course with a different aim and topic, namely computer and internetbased systems for information discovery in a scientific environment. This was also funded and the resulting workshop was running in parallel at the same location. As mastering information discovery systems is a component of information literacy in higher education, the two projects and workshops were organized in synergy. Participants to one workshop could also participate to the other workshop.

Furthermore, the two workshops could also be attended by the participants to the International Training Program named Lib@Web, which deals with the transition of university libraries to WWW-based systems for access to scientific information. Thus, the last two weeks of that Program consisted of the two workshops described above. 
Information Literacy Didactics

The synergy of the three activities resulted in more productivity and output based on the limited amounts of funding.

\section{Information Literacy Didactics in Other International Co- Operation Projects}

Didactics of information literacy has also been a component in other projects supported by VLIR, including the following:

- The inter-university co-operation program with the University of Burundi in Central Africa. In particular, one project aimed at increasing applications of information technology. This includes work with the university library. The results should also be incorporated in their activities to upgrade the information literacy of their users/clients.

- The inter-university co-operation program with Jimma University in Ethiopia, East Africa, plus a North-South-South project on higher education in information science, in which Jimma University is one of the partners.

\section{Methods}

The findings reported below are mainly based on the experience gained from the projects and other activities that are outlined above in the Introduction. In particular, the following actions have helped to obtain a concrete view on challenges in information literacy education in universities:

- the presentations by experts in some aspect of information literacy education, who were invited to the workshop

- the presentations by each project workshop participant on their own experience with information literacy training in their respective country

- the discussions among project workshop participants from various countries

- the brief presentation by each participant on how they plan to apply what they learned during the workshop

- the final group report from all participants presented at the end of the workshop

Also continuous monitoring of the state of the art through conferences and publications has helped to sharpen our view.

\section{Findings and Recommendations}

Most of the following findings are interrelated. Each finding leads to a recommendation related to future actions, by ourselves and by colleagues in other countries, who are also involved with information literacy didactics.

These challenges and recommendations are based on an international workshop with a significant heterogeneity among participants and their universities; therefore it is considered as reasonable and justified to formulate the statements as valid and applicable in most universities; nevertheless, a completely general applicability to all possible environments is of course not claimed.

\section{More Co-Operation among Universities is Desirable}

It is common that handouts, slides, online guides and related materials are used to train clients in live sessions or in online tutorials. A suitable WWW site must be offered to guide clients to information sources and services. We found that these aids are in many cases developed from 
scratch or based on materials found online, but that real, advanced co-operation in the development of such materials is almost absent. A reason for this absence of co-operation is the heterogeneity among organizations for higher education, as outlined below.

Recommendation: More cooperation may save time and efforts; therefore possible joint projects should at least be considered. Separation between universal topics and local topics makes it easier to co-operate and to reuse existing materials.

\section{Heterogeneity among Organizations for Higher Education Hinders Co-Operation}

The target audience of the workshop was largely homogeneous in the sense that the participants were mainly experts from libraries of universities in developing countries, with a history of cooperation with universities in Belgium. Nevertheless, the heterogeneity in the context of the workshop was obvious, due to differences in language, culture, religion, available budgets, range of acquired experience, etc. This heterogeneity can hinder of course the development of one strategy that is suitable for all universities and the co-operation among partner universities.

Recommendation: Recognize and assimilate this heterogeneity and the value of diversity. Stimulate the advanced universities to share their progress with less advanced partners.

The following gives an example. The librarian who participated to the workshop in Belgium has organized a follow-up workshop in her university in Pune, Maharashtra, India. She has invited experts from Belgium and from India to contribute, and also welcomed participants from less developed countries. More information is available online from http://aissmslibraryworkshop.weebly.com/

\section{Information Literacy is Competing with Media Literacy}

Libraries evolve towards digital media alongside more classical printed, hard-copy media. Also library efforts to increase the level of information literacy in their community are becoming more oriented towards digital media. But information literacy is of course overlapping with more general media literacy. This overlap is growing in the sense that some understanding of information technology, including computers, internet and the WWW, is required to exploit digital information sources and services. However, media literacy is in many cases taken care of by technology-oriented departments, while information literacy stays in the domain of what used to be the classical library. Co-operation and integration of information literacy and media literacy is still scarce, due to the virtual and real walls between departments in one university.

Recommendation: Consider the advantages of integrating training in information literacy with training in digital literacy or media literacy. In view of the increasing importance of digital media and related budgets, plus on the other hand the decreasing importance of classical libraries, and the related budgets, it may be wise for libraries to join forces with departments that have always been dealing with information technology.

\section{Leadership and Responsibility are Needed in Information Literacy Education}

Within each university, several staff members can be involved in information literacy education; these can be teaching staff, technical experts, or members of library staff. However, an agreement on aims, methods and responsibilities is lacking in many organizations. Even when the university library wants to devote efforts in this area, it is not always clear who is doing what and who carries a responsibility. Experts involved in a library can be subject specialists, information system 
experts, a web developer, an acquisition librarian, and so on. This hinders progress and can cause outdated training materials and links on the library website.

Recommendation: Agree within each university on aims, tasks and responsibilities related to information literacy training/education, so that materials and software is kept up to date and so that the responsible person can strive to a high level of professional expertise and job satisfaction.

\section{Developing Information Literacy Training Materials Requires An Adequate Budget}

Education and training cost money. More concretely, educating and guiding clients in the area of information literacy can involve the development of training materials, plus a website to make these materials available online, plus the organization of live training sessions. All this obviously requires an adequate budget (personnel time and funds). Furthermore, due to the fast evolution of the information landscape, updating is also required on a regular basis. This has been clearly illustrated in the workshop. The primary developer of a university web site on information literacy presented the result; the site and study materials look simple, but it has required many months of development and it requires regular updating.

Recommendation: Before making efforts or commitments, find out which budget would be adequate and make sure that this will be available at the start and also in the future.

\section{Expertise in Didactics is also Needed for Teaching in the Area of Information Literacy}

Education and training requires not only expertise in a specific subject area, but also skills related to the teaching/training process, in other words: didactical skills. This general rule should of course also be applied when we think of information literacy didactics. A particular, additional difficulty is that many librarians are quiet, introspective persons who may not be happy with the role of a teacher. This difficulty can be hard to overcome in small libraries with only a small number of staff members.

Recommendation: When a library starts some efforts in information literacy training, then the need for enthusiasm to train and teaching skills should be available among the involved staff members. Staff members can and should learn how to grow and become better guides, teachers and trainers. Recruiting a suitable staff member with a specific interest in training can be desirable.

\section{Marketing Should Support Information Literacy Didactics}

In some universities, we observe the following scenario. The library makes efforts to train students in information literacy, by preparing teaching materials and by organizing live sessions for invited students. However, not many students are enthusiastic to spend time in this way, so that only few or none come to the organized sessions. This then discourages and demotivates the staff members of the library. In the end, efforts in the domain of information literacy are skipped and progress is stopped. This problem is caused by several factors. One is a lack of skills and efforts at the side of the library in marketing their services and in publicizing the importance of information literacy for their clients. Also university managers should be convinced of the importance of information literacy.

Recommendation: When an information service makes efforts towards a higher degree of information literacy of their clients, then they should not underestimate the need and importance of marketing to reach and motivate their clients. 


\section{Information Literacy Should Be Integrated in the Curriculum of All Students}

Ideally, information literacy should be part of any curriculum for all students. So the level required at the end of a study should be clear and each student should be tested to check if an adequate level has been reached. Therefore, skills related to information usage and services should be integrated well with skills related to scientific research, with ethical behavior in science, with personal information management, skills related to the presentation and communication of scientific information and so on. Integration of information literacy with subjects that are closer to the core of the curriculum can also increase the motivation of a student to spend more time on information literacy. However, in most universities this desirable integration is (still) weak. Many libraries want to contribute to information literacy, but they see the more ambitious integration as unrealistic and too difficult to achieve.

Recommendation: Besides making efforts related to information literacy, consider also the importance of the higher goal of integrating information literacy in a deeper and more regular, normal way in the curricula, in the time budget and in the exams/tests of all students. Building and maintaining constructive links with faculty members can be fruitful to make progress in this context.

\section{Libraries Should Not Neglect Contemporary Information Systems}

Classical library products and services, such as acquisitions of expensive information sources and discovery services, reading rooms, catalogs, etc... remain valuable and important for the clients. However, besides these products and services, students and faculty have increasingly access to relevant other sources and services, online through the internet and the WWW. Many of these new tools can be accessed and used anytime, anywhere, and even free of charge. Such new digital tools available free of charge are neglected by some libraries or even considered as enemies of the library, which want to replace more classical library functions. Examples are open access journals, Academia.edu, Google Scholar, Mendeley, Researchgate, Zotero... This can have consequences for information literacy training: library staff members may not consider themselves as experts in the new tools, and may also leave these out from their training activities, from their web guides, etc. So this brings the danger of a distance and even a growing distance between the library and the reality of daily work and tools of students and faculty.

Recommendation: Libraries and their efforts in information literacy should incorporate new digital tools and services, even though these may be considered as far away from the core functions of the library.

\section{Study Materials Should be Adapted to the Upcoming Mobile Information Technology Tools}

Mobile tools and devices such as smartphones and small computers without keyboard grow in popularity and thus also in importance. The consequence for information literacy is that each library should also direct their sources, services, guides and trainings to their clients and potential clients in ways that are suitable for such mobile devices. This trend seems less prominent in Europe than in Africa and Asia.

Recommendation: Libraries should adapt their products, services and guides, so that clients can use and enjoy them by using mobile devices with a somewhat limited user interface. Therefore it may be wise to choose a software platform for web development that is able to create a website that formats and delivers output in such a way that is adapted to the display used by the client and 
Information Literacy Didactics

optimized for instance for a limited display area, in an automatic way; this can lower the development costs.

\section{Regional Training and Workshops on Information Literacy Didactics Would be Welcome}

In view of all the challenges, pitfalls, needs and recommendations mentioned above, participants to the workshop felt the need for more training on information literacy didactics. Some clearly expressed this need by considering the possibilities to organize similar workshops in their own region. Of course budgetary constraints hinder such enthusiastic reactions. Nevertheless, a workshop of one week has been prepared and organized in Pune, Maharashtra, India, in 2015, as a result of the co-operation between the organizers of the workshop in Belgium and the participant from Pune. More information is available online from the web site created for this workshop (http://aissmslibraryworkshop.weebly.com/).

Recommendation: Information literacy didactics is a valuable topic that deserves more local or regional attention and efforts in the form of meetings, conferences, workshops, train the trainer events, etc.

\section{Data Management Skills Become Important Besides Information Literacy}

Besides more classical information management, advanced students and professional researchers also have to manage the raw data obtained in their investigations, from which the new information and knowledge is extracted. This is a vibrant topic, at least in the USA and Europe. Research funding agencies increasingly demand adequate data management, conservation and accessibility. This provides a focus for potential re-usage and re-analysis of data by other researchers, plus lowering the occurrence of scientific fraud. In many cases in Europe, libraries are involved in and become responsible for education and guidance in data management. So data management skills can form an extension of information literacy skills and students and teachers should spend even more time and efforts to reach an adequate level of expertise in this growing area.

Recommendation: Consider the importance of data management skills besides information literacy. Consider integration of information plus data management or alternatively see that training in data management receives attention besides training in information literacy. At least see that responsibility is assigned to a suitable department.

\section{Conclusion}

The activities and findings reported above have helped to get a better view on the status of didactics in the area of information literacy in our own region as well as in several developing countries. We hope that this leads to more efficient actions and to more international cooperation in this important activity of information services, including libraries that support higher education and research.

Possible follow-ups to the activities and findings reported above, that we consider as reasonable include the following:

- More local workshops in various universities on information literacy \& services \& management. At least one has already been organized by a participant to the workshop reported in this paper, in Pune, India in 2015. 
- Another international workshop on information literacy didactics with participants from various, diverse countries, in which each participant does not present their own activities, but instead inspects the website of the department of the university of another participant, that contributes to information literacy education. In this way all participants can learn from each other about information literacy didactics implemented in practice and also about how the domain of information literacy is presented and made available to the stakeholders at each university through their university website.

\section{References}

Jacobson, T. E., \& Mackey, T. P. (Eds). (2016). Metaliteracy in practice. London : Facet Publishing.

Kurbanoglu, S. (Ed.). (2013). Worldwide Commonalities and Challenges in Information Literacy Research and Practice: European Conference on Information Literacy, ECIL 2013, Springer.

Kurbanoglu, S. (Ed.) et al. (2014). Information Literacy: Lifelong Learning and Digital Citizenship in the 21st Century: Second European Conference, ECIL 2014, Dubrovnik, Croatia, October 20-23, 2014. Proceedings (Paperback), Springer.

Nieuwenhuysen, P. (2010). An international training program in library and information science: Looking Backward and Forward. Education for Information, 28(2-4), 279-290, DOI 10.3233/EFI-2010-0909 http://www.iospress.nl/journal/education-for-information/

Preprint available free of charge from http://www.vub.ac.be/BIBLIO/nieuwenhuysen/presentations/

For further reading on information literacy education, see also the bibliography in the toolkit created for the project.

\section{Appendix}

\section{Steering group / advisory group for the project and workshop on information literacy didactics}

The following experts from higher education organizations in the region Flanders of Belgium have provided advice, assured the high quality of the project and selected the participants to the workshop:

- $\quad$ Piet De Keyser, University College Leuven-Limburg

- $\quad$ Raf Dekeyser, KULeuven

- $\quad$ Egbert de Smet, Universiteit Antwerpen

- $\quad$ Marc Goovaerts, Universiteit Hasselt

- $\quad$ Ludo Hoolans, KULeuven

- $\quad$ Paul Nieuwenhuysen, Vrije Universiteit Brussel

- Inge Van Nieuwerburgh, Universiteit Gent

- Wim Van Peteghem, KULeuven 


\section{Invitation and selection of participants to the workshop on didactics in information literacy}

For the workshop, a call for participation was written and posted on the WWW:

http://www.vliruos.be/en/project-funding/calls-for-applications/calldetail/call-for-participation-inworkshops-on-library-and-information-management_6145/

The workshop was open to librarians and information specialists involved in VLIR-UOS projects as well as to ex-participants to International Training Programs on information management, named Stimulate and Lib@Web.

The selection of the participants was mainly based on the received reports that have been written by applicants/candidates on their activities related to information literacy.

In this report the candidate demonstrated their relevant experience by answering the following questions:

- How are the patrons (researchers and students) informed about and trained in the use of information, including e-resources?

- How are the librarians informed about and trained in the use of information, including eresources?

- Do you train librarians or patrons (researchers and students)?

- Do you have a specific tutorial for your University/Institute? Do you use a tutorial from another University/Institute? Is it online or on paper?

- What kind of problems do you experience concerning training in the use of information?

- Which improvements do you suggest?

- Did you conduct any survey or kind of follow-up after the training?

Table 1: Participants to the workshop on information literacy didactics

\begin{tabular}{|l|l|l|l|l|}
\hline $\begin{array}{l}\text { Asaye } \\
\text { Birhanu }\end{array}$ & $\begin{array}{l}\text { Library ICT } \\
\text { Team Leader }\end{array}$ & Jimma University & Ethiopia & \\
\hline $\begin{array}{l}\text { Vrushali } \\
\text { Dandawate }\end{array}$ & Librarian & $\begin{array}{l}\text { AISSMS College } \\
\text { of Engineering, } \\
\text { Pune }\end{array}$ & India & \\
\hline $\begin{array}{l}\text { Lauren } \\
\text { Kipaan }\end{array}$ & Librarian & $\begin{array}{l}\text { Benguet State Uni- } \\
\text { versity, La Trini- } \\
\text { dad, Benguet }\end{array}$ & Philippines & \\
\hline $\begin{array}{l}\text { Grizly } \\
\text { Placeres }\end{array}$ & $\begin{array}{l}\text { Head of Infor- } \\
\text { mation Science } \\
\text { Department }\end{array}$ & $\begin{array}{l}\text { Central University } \\
\text { of Las Villas }\end{array}$ & Cuba & \\
\hline $\begin{array}{l}\text { Shehaamah } \\
\text { Mohamed }\end{array}$ & Senior Librarian & $\begin{array}{l}\text { University of the } \\
\text { Western Cape, } \\
\text { Belville }\end{array}$ & South Africa & \\
\hline
\end{tabular}




\begin{tabular}{|c|c|c|c|c|}
\hline $\begin{array}{l}\text { Andrew } \\
\text { Mwesigwa }\end{array}$ & $\begin{array}{l}\text { Academic Li- } \\
\text { brarian }\end{array}$ & $\begin{array}{l}\text { Makerere Universi- } \\
\text { ty Library }\end{array}$ & Uganda & \\
\hline $\begin{array}{l}\text { Fredrick } \\
\text { Wawire } \\
\text { Otike }\end{array}$ & Librarian & $\begin{array}{l}\text { Dedan Kimathi } \\
\text { University of } \\
\text { Technology }\end{array}$ & Kenya & \\
\hline $\begin{array}{l}\text { Bert } \\
\text { Alikromo }\end{array}$ & $\begin{array}{l}\text { Information Me- } \\
\text { diator }\end{array}$ & $\begin{array}{l}\text { Library Albert de } \\
\text { Krom University } \\
\text { of Suriname }\end{array}$ & Suriname & $\begin{array}{l}\text { Participant using } \\
\text { budget of VLIR In- } \\
\text { ternational Universi- } \\
\text { ty Co-operation pro- } \\
\text { ject }\end{array}$ \\
\hline $\begin{array}{l}\text { Maria There- } \\
\text { sa } \\
\text { Marquez }\end{array}$ & College librarian & $\begin{array}{l}\text { Benguet State Uni- } \\
\text { versity }\end{array}$ & Philippines & $\begin{array}{l}\text { Participant using her } \\
\text { own budget }\end{array}$ \\
\hline
\end{tabular}

\section{Program of the workshop on didactics of information literacy}

The coordinator of the workshop, Natalie Kerssebeeck, welcomed the participants and explained the goal, the program, the website and the social activities.

The keynote speech was presented by Paul Nieuwenhuysen, Vrije Universiteit Brussel. He gave an overview of the definitions, problems and challenges of information literacy in universities. The slides prepared to support this lecture should be available on the WWW:

http://www.vub.ac.be/BIBLIO/nieuwenhuysen/presentations/2014-12-infolit-antwerp/ or https://www.leuvenuniversitycollege.be/lib/shared/content/bijlagen/2014_12 infolit_antwerpen_n ieuwenhuysen_slides_4_1.pdf

Each participant contributed as follows:

- A 30 minutes presentation on the experiences they have with information literacy training in their library.

- A daily activity report: every day there was another reporter, who presented this report the next morning. All day reports can be found on the workshop's website.

- An active contribution in the discussions.

- A short final presentation on how the workshop has contributed to improve the information literacy training in their own library.

- An active participation in the final group report.

Presentations by experts:

- Jan Bollansée (KULeuven) presented the new online information literacy tutorial on the WWW for the Association KULeuven.

- Sven Cerulus (KHLeuven / University College Leuven-Limburg) is a lecturer in languages, not a librarian; he offered a good example of how information literacy can be integrated in the curriculum.

- M. Khatun (from Bangladesh and living in Antwerp, Belgium) presented social aspects of information literacy: the learning process, the learning experience, user's needs, 
training and barriers of library professionals. She ended her presentation by showing a few examples of good online information literacy training tutorials.

- R. Crookes presented the approach to training by the company EBSCO that serves mainly the library community.

- S. Duvigneau (IDS / BLDS) focused on teaching and assessment practices. A very informative instrument is the IDS Training Toolkit: http://opendocs.ids.ac.uk/opendocs/handle/123456789/2893\#.VWSuAUbcAmt

Practical sessions:

- Egbert De Smet (University of Antwerp) showed the possibility to use the library and information management software $\mathrm{ABCD}$ to manage e-resources and information literacy resources.

- Pieter Lernout (Hasselt University Library) showed the use of WordPress as a content management system to manage the output of a workshop or to develop a website on information literacy.

- Dries Moreels (Ghent University Library) showed the use of LibreCat to integrate metadata excerpted from full-text documents and from social media tools such as Zotero and Mendeley.

- J. Rahman (from Bangladesh and working at University of Antwerp) demonstrated eXelearning, an easy-to-use tool to create learning environments, for instance to support learning in information literacy.

The workshop's program, all presentations, the daily activity reports, the final presentations of the participants and the group report are available on the workshop's website:

http://www.leuvenuniversitycollege.be/lib/Information-literacy/VLIR-UOS-workshop

\section{Toolkit on information literacy didactics}

The toolkit can be freely accessed on the WWW:

http://www.leuvenuniversitycollege.be/lib/Information-literacy

The contents:

- An introduction to definitions and standards in the field of information literacy

- All the workshop's information: introduction, program, all presentations, daily reports, final presentations of the participants

- A bibliography on information literacy

- Links to portals related to information literacy

- Links to blogs about information literacy

- Links to organizations dealing with information literacy

- Links to conferences with information literacy as a topic

- Links to tutorials on information literacy

- Links to tools related to information literacy didactics

This toolbox can be updated even after the project period. 


\section{Biography}

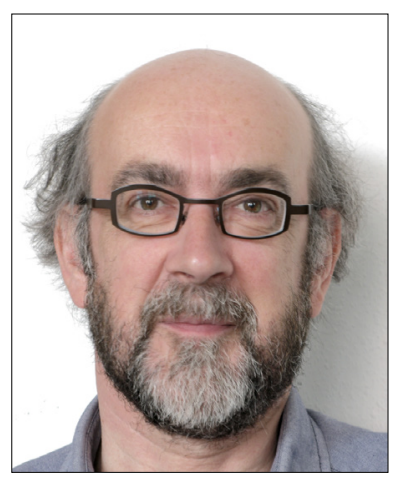

Paul Nieuwenhuysen has been a member of the academic staff at the Vrije Universiteit Brussel since 1983, nowadays as professor. His functions have included: member of the management board of the University Library, librarian for science and engineering, as well as teaching courses on online information retrieval and presentation.

At the University of Antwerp inter-university postgraduate program in Information and Library Science, he has been guest professor responsible for courses on information technology and on the information market until 2009.

At the University of Antwerp he received the degrees of Licentiaat in Physics in 1974, Doctor in Science in 1979, the Belgian post-doctoral degree (named Geaggregeerde voor het Hoger Onderwijs) in 1983, and the inter-university postgraduate degree in Documentation and Library Science in 1986.

More information is available from http://www.vub.ac.be/BIBLIO/nieuwenhuysen/professional/index.html 